\title{
Acute radiodermatitis in cancer patients: incidence and severity estimates*
}

\section{Radiodermatite aguda em pacientes com câncer: estimativa de incidência e severidade Radiodermatitis aguda en pacientes con cáncer: estimación de la incidencia y la severidad}

How to cite this article:

Bontempo PSM, Ciol MA, Menêses AG, Simino GPR, Ferreira EB, Reis PED. Acute radiodermatitis in cancer patients: incidence and severity estimates. Rev Esc Enferm USP. 2021;55:e03676. doi: https://doi.org/10.1590/S1980-220X2019021703676

Priscila de Souza Maggi Bontempo $^{1}$

\section{Darcia Aparecida $\mathrm{Ciol}^{2}$ \\ Amanda Gomes de Menêses ${ }^{1}$ \\ Giovana Paula Rezende Simino ${ }^{3}$ \\ Elaine Barros Ferreira ${ }^{1}$ \\ Paula Elaine Diniz dos Reis ${ }^{1}$}

* Extracted from the dissertation: "Ocorrência de radiodermatite em pacientes com câncer em um hospital de ensino de Brasília”, Programa de Pós-Graduação em Enfermagem, Universidade de Brasília, 2017.

${ }^{1}$ Universidade de Brasília, Faculdade de Ciências da Saúde, Programa de Pós-Graduação em Enfermagem, Brasilia, DF, Brazil.

${ }^{2}$ University of Washington, School of Medicine, Department of Rehabilitation Medicine, Seattle, WA, USA.

${ }^{3}$ Universidade Federal de Minas Gerais, Belo Horizonte, MG, Brazil.

\begin{abstract}
Objective: To estimate the incidence and distribution of the degree of radiodermatitis in cancer patients submitted to radiotherapy in the regions of head and neck, breast, and pelvis. Method: Prospective, longitudinal, quantitative study conducted from March 15, 2016 to May 4, 2017 with patients observed for five weeks of treatment. The primary outcome was the proportion of grade 1 or higher radiodermatitis each week. The degree of radiodermatitis and mean time of occurrence for each patient were secondary outcomes. Results: This study included 112 patients. The incidence of radiodermatitis was $100 \%$ among those whose head and neck region was irradiated, followed by $98 \%$ for breast and $48 \%$ for the pelvic region. The degree of radiodermatitis varied with the irradiated site; the worst degrees were found in the head and neck region, followed by the breast. In the three groups, the mean time of the first occurrence of radiodermatitis was approximately eleven days. Conclusion: The incidence of radiodermatitis in the studied groups was high, which reinforces the need to perform the same evaluation nationwide. This would support creating and standardizing protocols and recommendations for a proper management of radiodermatitis, specially concerning its prevention.
\end{abstract}

\section{DESCRIPTORS}

Radiodermatitis; Head and Neck Neoplasms; Breast Neoplasms; Pelvic Neoplasms; Oncology Nursing. 


\section{INTRODUCTION}

Radiodermatitis is a cutaneous reaction to ionizing radiation exposure which varies from mild erythema to severer reactions, such as dry or moist desquamation. This reaction is commonly reported by the international literature to afflict cancer patients who undergo irradiation of the regions of head and neck, breast, and pelvis, whose skin is part of the target irradiation area ${ }^{(1-2)}$. However, the incidence of this reaction in Brazil is unknown.

The pathogenesis of radiodermatitis results from cell damage due to ionizing radiation exposure followed by an inflammatory response which affects skin layers (epidermis, dermis, and hypodermis or subcutaneous tissue) ${ }^{(2)}$. Such cell damage takes place direct or indirectly by the formation of reactive oxygen species and impacts essentially the capacity of cell division and multiplication ${ }^{(3-4)}$. Actively proliferating cells are thus, similarly to the basal cells constituting the epidermis, more radiosensitive ${ }^{(2)}$.

The skin presents a balanced system of cell production and destruction in the epidermis (basal layer). This balance is broken after the first radiotherapy session, when keratinocyte destruction starts. With subsequent radiotherapy sessions, there is an accumulation of dose, increasing unbalance, which predisposes to changes to epidermis integrity and skin healing processes. Such changes surface with the appearance of erythema, xerosis, desquamation, itching, and hyperpigmentation ${ }^{(1,5)}$.

Erythema develops from a response to damage to the skin basal layer and as a consequence of an inflammatory process which initiates with histamine release and hypervascularity. It occurs around 10 to 14 days after radiotherapy ${ }^{(1,6)}$ in patients receiving doses between 6 and 20 Gy and may be associated to symptoms such as discomfort, itching, and xerosis ${ }^{(6)}$.

After three to four weeks of treatment, as a compensatory response, mitotic activity is increased and stimulates the migration of new cells to substitute the damaged ones. The new cells are produced faster than the old ones are eliminated, originating dry desquamation, common in doses higher than 20 Gy. Continuous exposure to radiotherapy decreases the capacity of the basal layer to efficiently produce new cells to substitute damaged cells, which results in epidermal detachment, release of serous fluid and formation of wet blisters, covering a partial or confluent area of the treated region. This reaction is called moist desquamation and may surface after doses higher than $30 \mathrm{~Gy}^{(6)}$.

The development of radiodermatitis and its severity are related to extrinsic and intrinsic factors. Extrinsic factors include the treatment (total dose, volume of irradiated area, fractionation, and planning technique) and intrinsic factors refer to the patient (age, genetic antecedents, molecular subtypes, size and shape of the irradiated area) $)^{(7-9)}$.

Acute radiodermatitis in severer degrees may limit the therapeutic dose of radiation ${ }^{(10)}$, contribute to delayed completion or even interruption of radiotherapy, causing a negative impact on therapy success ${ }^{(1,11-12)}$. Also, radiodermatitis is responsible for aesthetic alterations, discomfort, pain, and reduced patient quality of life ${ }^{(12)}$.
The available literature presents a gap concerning the incidence of radiodermatitis in Brazil and, although the physiopathology of radiodermatitis is known, studies presenting the distribution of the degree of radiodermatitis throughout treatment for each irradiated area are also required. Obtaining this data may contribute to establishing common grounds and recommendations for managing radiodermatitis. This study's objective was thus verifying the incidence of radiodermatitis in cancer patients submitted to radiotherapy in the regions of head and neck, breast, and pelvis.

\section{METHOD}

\section{Study DESIGN}

Prospective, longitudinal, quantitative study.

\section{SCENARIO}

A radiotherapy outpatient clinic of a High Complexity Oncology Unit (Unidade de Alta Complexidade em Oncologia - UNACON) of the University Hospital of Brasília (Hospital Universitário de Brasilia - HUB), associated to Universidade de Brasília (UnB).

\section{SELECTION CRITERIA}

The sample comprised all patients with cancer in the regions of head and neck, breast, or pelvis (prostate, cervix, and endometrium) submitted to radiotherapy from March 15, 2016 to May 4, 2017 who agreed to participate in the study. The patients were treated in a radiotherapy device of the type Linear Accelerator manufactured by VARIAN, model CLINAC CX, employing a three-dimensional conformal (3D - CRT) planning.

The inclusion criteria were patients aged 18 or older with an indication to start radiotherapy for treatment of head and neck, breast, or pelvis (prostate, cervix, and endometrium) cancer in any clinical stage. The exclusion criteria were: patients with an indication of urgent radiotherapy due to tumor complications (superior vena cava syndrome, medullary compression syndrome, intracranial hypertension syndrome, and hemorrhage), patients with tumor wounds in the treatment region which could interfere with the evaluation of radiodermatitis, and patients with a record of radiotherapy of the evaluated region.

\section{Data collection}

The participants were recruited during the nursing consultation carried out in the first day of radiotherapy in the outpatient unit of UNACON/HUB. After receiving information about the necessary cautions during radiotherapy according to the routine of the nursing outpatient unit, the patients were invited to participate in the study. After receiving the necessary information about the research during the nursing consultation and agreeing to participate, the patients signed the Informed Consent Form (ICF).

General recommendations of care with irradiated skin area include cleaning the skin with mild soap, hydrating the skin with water-based creams, photoprotection, and avoiding skin 
friction $^{(13)}$. Also, for each degree of radiodermatitis, specific topical products were indicated, namely: chamomile gel (used in a prophylactic way when patients have intact skin and in case of erythema), chamomile tea compress in case of dry desquamation, and silver sulfadiazine for moist desquamation ${ }^{(13)}$.

In this first consultation, patients' sociodemographic and clinical data were collected, in addition to a skin evaluation abiding by the radiodermatitis classification criteria of the Oncology Nursing Society (ONS) ${ }^{(14)}$. Also, a photograph of their skin was taken with a Nikon - Coolpix P510 digital camera, excluding patients who had pelvic tumors, since this is an intimate area. For such patients, evaluation was performed through visual inspection of the treatment area by the nurse. The classification proposed by $\mathrm{ONS}^{(14)}$ was employed to measure the degree of radiodermatitis: (0) no change, (1.0) faint or dull erythema, (1.5) bright erythema, (2.0) dry desquamation with or without erythema, (2.5) small to moderate amount of moist desquamation, (3.0) confluent moist desquamation, and (3.5) ulceration, hemorrhage, or necrosis.

The sociodemographic and clinical characteristics collected were: age (in years), gender (feminine or masculine), self-reported color (white, brown or black), educational level (illiterate, primary, secondary, or superior), smoking status (smoker, former smoker or never smoked), drinking status (drinker, former drinker or never drank), presence of diabetes, daily sun exposure, Performance Status, tumor location, current treatment (chemotherapy, radiotherapy or chemoradiotherapy), type of energy, and total dose (Gy). Also, for participants with breast cancer, Body Mass Index (BMI) was collected and transformed into the following classification: Obese $\left(\mathrm{BMI} \geq 30 \mathrm{~kg} / \mathrm{m}^{2}\right)$, Overweight $(\mathrm{BMI}>25$ and < $29.9 \mathrm{Kg} / \mathrm{m}^{2}$ ), Normal Weight (BMI >18.5 and < $24.9 \mathrm{Kg} /$ $\mathrm{m}^{2}$ ) and Underweight $\left(\mathrm{BMI}<18.5 \mathrm{Kg} / \mathrm{m}^{2}\right)$, as well as bra size (Brazilian sizes: 42, 44, 46, 48, 50). All these variables were registered in a self-created instrument.

The nurse researcher evaluated the participants every week during the treatment, following the ONS criteria ${ }^{(14)}$ for assessing skin integrity, occurrence of radiodermatitis, and photographic register (except pelvis). The patients were followed up during the phase 1 of the treatment (five weeks) since some of them had to wait for further therapeutic planning to proceed to subsequent treatment phases and radiodermatitis assessment would not be continuous.

\section{DATA TREATMENT AND ANALYSIS}

The sociodemographic and clinical characteristics were presented in a descriptive manner.

The primary outcome was the presence of radiodermatitis, defined as the emergence of grade 1 or higher radiodermatitis during the treatment weeks. Each week, the proportion of patients presenting radiodermatitis was calculated and the estimate and 95\% confidence interval were calculated by Bayesian method (using Jeffreys prior).

Concerning the secondary outcomes, the distribution of the degree of radiodermatitis by week was presented in a descriptive manner and the means, medians, standard deviation and extreme values of the time in days until the first observation of radiodermatitis within each group (head and neck, breast, and pelvis) were calculated.

The analyses of mean and frequency were carried out using SPSS version 25 for Mac, and the confidence interval for proportions and graphs was calculated with the software RStudio.

\section{ETHICAL ASPECTS}

The research project was approved by the Research Ethics Committee of the Health Sciences Faculty of UnB in Opinion 610.425, dated 2013, following the recommendations of Resolution 466/12 by the National Health Council concerning research with human subjects. All participants have signed the Informed Consent Form.

\section{RESULTS}

Out of 163 evaluated patients, 50 were non-eligible (30 presented tumor wounds in the irradiated region and 20 had received urgent radiotherapy). Among eligible patients, one refused participation and 112 were included (31 with head and neck cancer, 50 with breast cancer, and 31 with cancer in the pelvis region). There was no loss to follow-up during the assessment period.

Clinical and sociodemographic characterization of participants is presented in Table 1 . The mean age of patients with head and neck cancer was 58.8 years (standard deviation $[\mathrm{SD}]=14.5$ years); $68 \%$ were male and $68 \%$ were white. The predominant tumor site was the oral cavity, identified in 13 (42\%) patients. Regarding the current treatment, 21 (68\%) were undergoing chemoradiotherapy and 10 (32\%) were undergoing exclusive radiotherapy. The treatment was conducted in a mean of 25 sessions, with a total dose of 50 $\mathrm{Gy}$; the type of energy used was photons.

The mean age of participants with breast cancer was 53 years $(\mathrm{SD}=13.4)$. The most frequent histological type in the sample was Invasive Ductal Carcinoma (94\%). Most participants were above the recommended weight: $40 \%$ were obese and 36\% were overweight (Table 1). Among participants who preserved their breast or underwent breast reconstruction, $16(32 \%)$ wore bras of a size between 42 and 46, 5 (10\%) used size 48, and 5 (10\%) used a size higher than 50. Fifteen patients (30\%) were receiving exclusive radiotherapy and 35 (70\%), radiotherapy concomitant to another therapy (trastuzumab or hormone therapy). Hypofractionated radiation, in which there is a reduction in the total number of fractions and increase in the administered daily dose, was conducted in 9 patients (18\%). The mean total radiotherapy dose was $48 \mathrm{~Gy}$ and the most employed type of energy was photons.

The mean age of patients who received pelvic radiotherapy was 62.4 years $(\mathrm{SD}=11)$. Most $(74 \%)$ had prostate cancer, followed by cervix cancer (16\%) and endometrium cancer (10\%). Seventeen patients (55\%) were submitted to radiotherapy concomitantly to hormone therapy, 7 (23\%) to chemoradiotherapy and seven $(23 \%)$ to exclusive radiotherapy. The mean total dose was $49 \mathrm{~Gy}$ (cervix), $50 \mathrm{~Gy}$ (endometrium), and $54 \mathrm{~Gy}$ (prostate). 
Table 1 - Sociodemographic and clinical characteristics of patients treated in the service between March 2016 and May 2017 - Brasília, DF, Brazil, 2018.

\begin{tabular}{lccc}
\hline & HN & Breast & Pelvis \\
\cline { 2 - 4 } $\begin{array}{l}\text { Sociodemographic and Clinical } \\
\text { Characteristics }\end{array}$ & $\begin{array}{c}\mathbf{n}= \\
\text { 31) }\end{array}$ & $(\mathbf{n}=\mathbf{5 0})$ & $(\mathbf{n}=\mathbf{3 1})$ \\
\hline $\begin{array}{l}\text { Age (years), mean (standard } \\
\text { deviation) }\end{array}$ & 58.8 & 53.0 & 62.4 \\
& $(14.5)$ & $(13.4)$ & $(11.0)$ \\
\multicolumn{1}{l}{ Median (min, max) } & 59 & 52 & 65 \\
& $(22.83)$ & $(26.84)$ & $(39.79)$ \\
\hline
\end{tabular}

Gender, n (\%)

\begin{tabular}{lccc} 
Male & $21(68)$ & $1(2)$ & $23(74)$ \\
Female & $10(32)$ & $49(98)$ & $8(26)$ \\
\hline
\end{tabular}

BMI categories, n (\%)

$\begin{array}{lccc}\text { Obese }\left(\mathrm{BMI} \geq 30 \mathrm{~kg} / \mathrm{m}^{2}\right) & - & 20(40) & - \\ \begin{array}{l}\text { Overweight }(\mathrm{BMI}>25 \text { and }< \\ \left.29.9 \mathrm{Kg} / \mathrm{m}^{2}\right)\end{array} & - & 18(36) & - \\ \begin{array}{l}\text { Normal Weight }(\mathrm{BMI}>18.5 \text { and } \\ \left.<24.9 \mathrm{Kg} / \mathrm{m}^{2}\right)\end{array} & - & 11(22) & - \\ \begin{array}{l}\text { Underweight }(\mathrm{BMI}<18.5 \mathrm{Kg} / \\ \left.\mathrm{m}^{2}\right)\end{array} & - & 1(2) & - \\ \text { Color } & & & \\ \text { White } & 21(68) & 21(42) & 10(32) \\ \text { Brown } & 9(29) & 24(48) & 5(16) \\ \text { Black } & 1(3) & 5(10) & 16(52)\end{array}$

Educational level

\begin{tabular}{|c|c|c|c|}
\hline Illiterate & $2(6)$ & $4(8)$ & $2(7)$ \\
\hline Primary & $19(62)$ & $14(28)$ & $16(52)$ \\
\hline Secondary & $9(27)$ & $27(54)$ & $9(29)$ \\
\hline Superior & $1(3)$ & $5(10)$ & $4(13)$ \\
\hline \multicolumn{4}{|l|}{ Smoking status } \\
\hline Smoker & $2(6)$ & $4(8)$ & $5(16)$ \\
\hline Former smoker & $25(81)$ & $16(32)$ & $14(45)$ \\
\hline Never smoked & $4(13)$ & $30(60)$ & $12(39)$ \\
\hline \multicolumn{4}{|l|}{ Drinking status } \\
\hline Drinker & $3(10)$ & $17(34)$ & $12(39)$ \\
\hline Former drinker & $23(74)$ & $2(4)$ & $10(32)$ \\
\hline Never drank & $5(16)$ & $31(62)$ & $9(29)$ \\
\hline Presence of diabetes, n (\%) & $5(16)$ & $10(20)$ & $6(19)$ \\
\hline Daily sun exposure, yes, n (\%) & $24(77)$ & $0(0)$ & $4(13)$ \\
\hline \multicolumn{4}{|l|}{ Performance Status (PS) } \\
\hline Normal activity (PS 0) & $29(94)$ & $43(86)$ & $28(90)$ \\
\hline $\begin{array}{l}\text { Presence of disease symptoms, } \\
\text { but able to ambulate and lead a } \\
\text { normal routine (PS 1) }\end{array}$ & $2(6)$ & $7(14)$ & $3(10)$ \\
\hline
\end{tabular}

RADIODERMATITIS IN PATIENTS RECEIVING RADIOTHERAPY IN THE REGION OF HEAD AND NECK

Table 2 presents the results for the occurrence and degree of radiodermatitis throughout time for patients whose region of head and neck was irradiated. All participants presented some degree of radiodermatitis during the treatment, with a mean time for first event occurrence of eleven days $(\mathrm{SD}=$ 5.4; median $=10[\min =5, \max =30])$. In the first week of treatment (W1), 35\% presented erythema, which increased to $68 \%$ in the second week (W2) and $87 \%$ in the third week (W3), out of which 7\% evolved to dry desquamation. From the fourth week onwards, the proportion of individuals with erythema decreased, but there was an increase in dry desquamation (33\%) and evolution to moist desquamation of a subject on week 4 and two on week 5 .

Table 2 - Number of participants with head and neck cancer by occurrence and degree of radiodermatitis in each treatment week - Brasília, DF, Brazil, 2018.

\begin{tabular}{|c|c|c|c|c|c|c|}
\hline \multirow{2}{*}{\multicolumn{2}{|c|}{$\begin{array}{l}\text { Degree of } \\
\text { Radiodermatitis }\end{array}$}} & \multicolumn{5}{|c|}{ Number of patients with radiodermatitis } \\
\hline & & \multirow{2}{*}{$\begin{array}{l}\text { W1 } \\
31\end{array}$} & \multirow{2}{*}{$\begin{array}{l}\text { W2 } \\
31\end{array}$} & \multirow{2}{*}{$\begin{array}{l}\text { W3 } \\
31\end{array}$} & \multirow{2}{*}{$\begin{array}{l}\text { W4 } \\
31\end{array}$} & \multirow{2}{*}{$\begin{array}{c}\text { W5 } \\
31\end{array}$} \\
\hline $\mathbf{n}$ & & & & & & \\
\hline 0 & No change & 20 & 10 & 2 & 1 & 2 \\
\hline 1 & $\begin{array}{l}\text { Faint or dull } \\
\text { erythema }\end{array}$ & 10 & 19 & 13 & 4 & 0 \\
\hline 1.5 & Bright erythema & 1 & 2 & 14 & 15 & 8 \\
\hline 2 & $\begin{array}{l}\text { Dry desquamation } \\
\text { with or without } \\
\text { erythema }\end{array}$ & 0 & 0 & 2 & 10 & 19 \\
\hline 2.5 & $\begin{array}{l}\text { Small to moderate } \\
\text { amount of moist } \\
\text { desquamation }\end{array}$ & 0 & 0 & 0 & 1 & 1 \\
\hline 3 & $\begin{array}{l}\text { Confluent moist } \\
\text { desquamation }\end{array}$ & 0 & 0 & 0 & 0 & 1 \\
\hline \multicolumn{2}{|c|}{$\begin{array}{l}\text { Proportion of patients } \\
\text { with grade } 1 \text { or higher } \\
\text { (95\% Confidence } \\
\text { Interval) }\end{array}$} & $\begin{array}{l}0.36 \\
(0.20 ; \\
0.52)\end{array}$ & $\begin{array}{c}0.67 \\
(0.51 \\
0.83)\end{array}$ & $\begin{array}{l}0.92 \\
(0.83 ; \\
0.99)\end{array}$ & $\begin{array}{l}0.95 \\
(0.88 \\
1)\end{array}$ & $\begin{array}{l}0.92 \\
(0.83 \\
0.99)\end{array}$ \\
\hline
\end{tabular}

Note: $(n=31)$.

\section{OCCURRENCE OF RADIODERMATITIS IN THE BREAST REGION}

Among participants irradiated in the breast region, 98\% acquired radiodermatitis during the treatment, with a mean time for first occurrence of radiodermatitis of eleven days $(\mathrm{SD}=3.7)$. Erythema was the predominant sign among patients; it was present in all five weeks of follow-up, especially in weeks 3 and 4 (Table 3). Dry desquamation occurred in Weeks 4 (W4) and 5 (W5), with 6\% and 10\%, respectively. Moist desquamation started in Week 3 (W3), with an increased frequency in subsequent weeks. No patient presented ulcer, hemorrhage, or necrosis during the treatment. 
Table 3 - Proportion of participants whose breast was irradiated by occurrence and degree of radiodermatitis in each treatment week - Brasília, DF, Brazil, 2018.

\begin{tabular}{|c|c|c|c|c|c|c|}
\hline \multirow{2}{*}{\multicolumn{2}{|c|}{$\begin{array}{l}\text { Degree of } \\
\text { Radiodermatitis }\end{array}$}} & \multicolumn{5}{|c|}{ Week (\%) } \\
\hline & & W1 & W2 & W3 & W4 & W5 \\
\hline \multicolumn{2}{|l|}{$\mathbf{n}$} & 50 & 50 & 48 & 43 & 32 \\
\hline 0 & No change & 42 & 17 & 5 & 1 & 1 \\
\hline 1 & $\begin{array}{l}\text { Faint or dull } \\
\text { erythema }\end{array}$ & 8 & 30 & 29 & 14 & 4 \\
\hline 1.5 & Bright erythema & 0 & 3 & 12 & 18 & 11 \\
\hline 2 & $\begin{array}{l}\text { Dry desquamation } \\
\text { with or without } \\
\text { erythema }\end{array}$ & 0 & 0 & 0 & 6 & 10 \\
\hline 2.5 & $\begin{array}{l}\text { Small to moderate } \\
\text { amount of moist } \\
\text { desquamation }\end{array}$ & 0 & 0 & 1 & 4 & 6 \\
\hline 3 & $\begin{array}{l}\text { Confluent moist } \\
\text { desquamation }\end{array}$ & 0 & 0 & 1 & 0 & 0 \\
\hline \multicolumn{2}{|c|}{$\begin{array}{l}\text { Proportion of patients } \\
\text { with grade } 1 \text { or higher } \\
\text { (95\% Confidence } \\
\text { Interval) }\end{array}$} & $\begin{array}{l}0.17 \\
(0.07 \\
0.27)\end{array}$ & $\begin{array}{l}0.66 \\
(0.53 \\
0.78)\end{array}$ & $\begin{array}{l}(0.80 ; \\
0.97)\end{array}$ & $\begin{array}{l}(0.91 ; \\
1)\end{array}$ & $\begin{array}{l}(0.88 ; \\
1)\end{array}$ \\
\hline
\end{tabular}

Note: $(n=50)$.

\section{OCCURRENCE OF RADIODERMATITIS IN THE PELVIC REGION}

Among patients with cervix cancer, four presented some degree of radiodermatitis, with a mean occurrence time of 7 days $(\mathrm{SD}=4.8)$. Among patients with endometrium cancer, only one presented radiodermatitis during the treatment, with an occurrence time of 11 days; among patients with prostate cancer, twelve presented radiodermatitis during the treatment and the mean time of occurrence was 18 days $(\mathrm{SD}=13)$, which was late when compared to the other regions.

Among patients whose pelvic region was irradiated, compared to the regions of head and neck and breast, there was a smaller occurrence of radiodermatitis (48.4\%). However, the occurrence of moist desquamation during all the weeks of evaluation (Table 4) in one or two individuals per week is emphasized.

Table 4 - Proportion of participants whose pelvic region was irradiated by occurrence and degree of radiodermatitis in each treatment week - Brasília, DF, Brazil, 2018.

\begin{tabular}{|c|c|c|c|c|c|c|}
\hline \multirow{2}{*}{\multicolumn{2}{|c|}{$\begin{array}{l}\text { Degree of } \\
\text { Radiodermatitis }\end{array}$}} & \multicolumn{5}{|c|}{ Week (\%) } \\
\hline & & W1 & W2 & W3 & W4 & W5 \\
\hline \multicolumn{2}{|l|}{$\mathbf{n}$} & 31 & 31 & 31 & 28 & 26 \\
\hline 0 & No change & 29 & 28 & 27 & 21 & 20 \\
\hline 1 & $\begin{array}{l}\text { Faint or dull } \\
\text { erythema }\end{array}$ & 1 & 1 & 2 & 4 & 5 \\
\hline 1.5 & Bright erythema & 0 & 0 & 1 & 2 & 0 \\
\hline 2 & $\begin{array}{l}\text { Dry desquamation } \\
\text { with or without } \\
\text { erythema }\end{array}$ & 0 & 0 & 0 & 0 & 0 \\
\hline 2.5 & $\begin{array}{l}\text { Small to moderate } \\
\text { amount of moist } \\
\text { desquamation }\end{array}$ & 1 & 2 & 1 & 1 & 1 \\
\hline \multicolumn{2}{|c|}{$\begin{array}{l}\text { Proportion of patients } \\
\text { with grade } 1 \text { or higher } \\
\text { (95\% Confidence } \\
\text { Interval) }\end{array}$} & $\begin{array}{l}0.08 \\
(0.01 ; \\
0.17)\end{array}$ & $\begin{array}{l}0.11 \\
(0.02 ; \\
0.22)\end{array}$ & $\begin{array}{l}0.14 \\
(0.03 ; \\
0.26)\end{array}$ & $\begin{array}{l}0.26 \\
(0.11 ; \\
0.42)\end{array}$ & $\begin{array}{l}(0.09 ; \\
0.40)\end{array}$ \\
\hline
\end{tabular}

Note: $(n=31)$

Figure 1 presents the proportion of patients who developed some degree of radiodermatitis by week of treatment according to the radiated region.
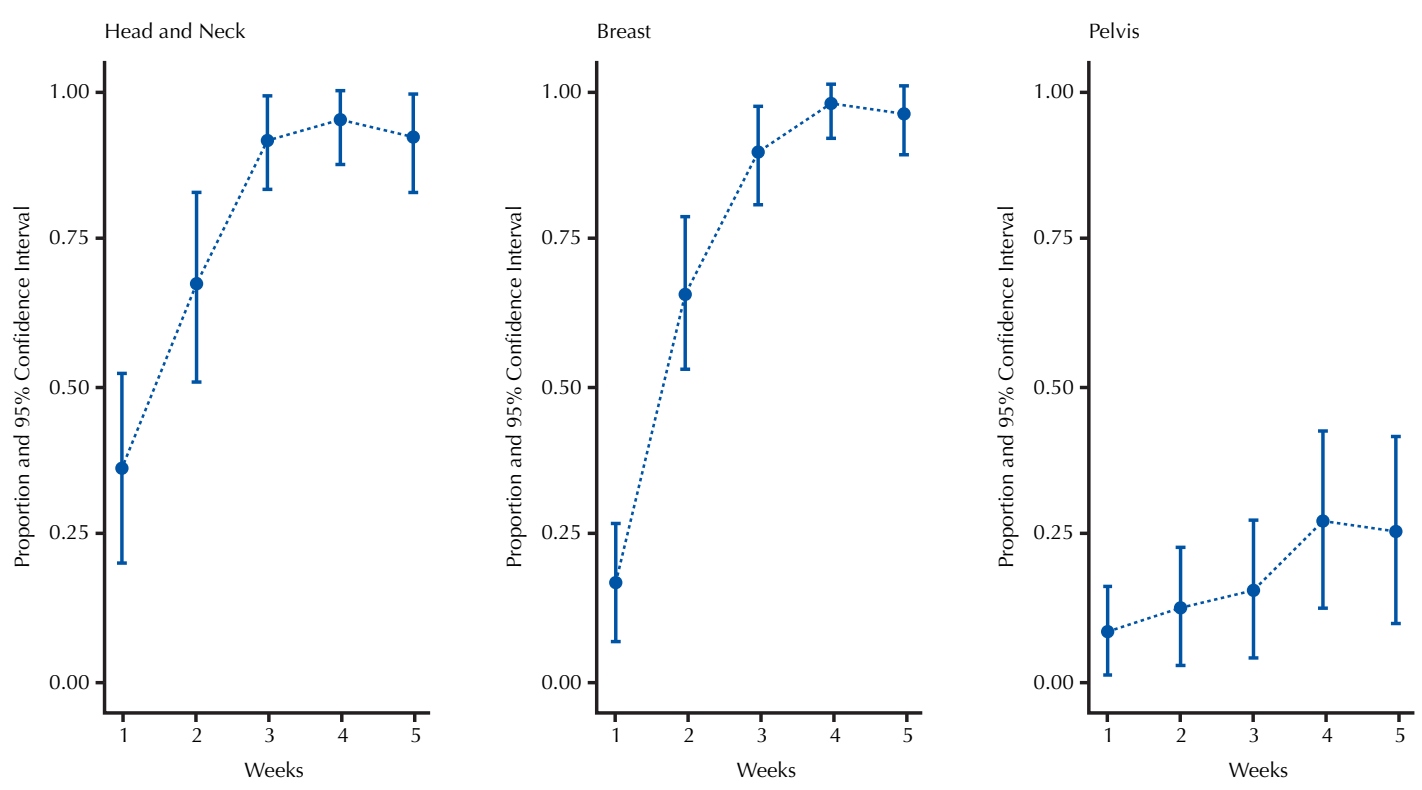

Figure 1 - Proportion and Confidence Interval of patients who presented radiodermatitis in the regions of head and neck, breast, and pelvis in five weeks - Brasília, DF, Brazil, 2018. 


\section{DISCUSSION}

In this study, the incidence of radiodermatitis among patients assisted in the Radiotherapy Outpatient Clinic of UNACON/HUB over a 14-month period was estimated. This is the first known Brazilian study to estimate the incidence of radiodermatitis in cancer patients submitted to radiotherapy. A total of 112 patients were followed-up, out of whom 31 had head and neck cancer, 50 had breast cancer, and 31 had a cancer in the pelvic region ( 23 prostate, 5 cervix, and 3 endometrium).

The incidence of radiodermatitis ranged from $48 \%$ to $100 \%$ and the time for development of radiodermatitis ranged from 7 to 18 days. These results are comparable to those found in the literature, according to which 90 to $95 \%$ of individuals submitted to radiotherapy develop some degree of radiodermatitis ${ }^{(15-16)}$ within a mean 10 to 14 days from the start of the treatment ${ }^{(17)}$. In patients whose breast region was irradiated, the incidence was $98 \%$, a figure similar to that found in the international literature, which varied from 95 to $100 \%{ }^{(18-19)}$.

Among patients whose pelvis was irradiated, the proportion of patients who developed some degree of radiodermatitis varied from $8 \%$ to $26 \%$; the literature does not present any data for the incidence of radiodermatitis in this population. The smaller incidence in this group may be hypothesized to be due to the fact that the areas for irradiation in the pelvic region are far from one another (anterior area, right side and left side) when compared to the regions of breast and head and neck, in which the areas for irradiation may overlap. The skin of the pelvic region may be thus more preserved regarding the accumulation of dose in the tissue.

Smoking may be an aggravating factor for the development of radiodermatitis since it hinders the process of skin healing ${ }^{(12,20)}$. This study's sample included a high number of smokers among patients whose region of head and neck was irradiated ( $81 \%$ had been smokers and $6 \%$ still were). Among patients with breast cancer, four (8\%) reported being smokers, among whom three presented moist desquamation during the treatment.

Breast size is also related to the development of radiodermatitis ${ }^{(6,21)}$. Cutaneous folds may be causes of friction, resulting in lesions; this is common in obese people. This may also occur in patients with voluminous breasts, particularly in the inframammary region ${ }^{(22)}$. In this study, patients with voluminous breasts developed more erythema when compared to those with smaller breasts. Also, the two patients with the most voluminous breasts of the sample (bra size 54) had BMI higher than $30 \mathrm{Kg} / \mathrm{m}^{2}$ (obese) and developed moist desquamation in the axillary and inframammary regions.
The time of occurrence and grade of radiodermatitis may be delayed if the care protocol recommended by nurses of the service is followed ${ }^{(23-24)}$. The recommendations provided by the literature for skin care during radiotherapy are simple and involve skin hydration through topical care and water intake, wearing appropriate clothing, and sun protection ${ }^{(13,25)}$. This study's patients received information on care of the irradiated region and it is possible that some have thus delayed the time of development of radiodermatitis.

It is extremely important for Brazilian radiotherapy services to quantify and characterize radiodermatitis developed in cancer patients submitted to radiotherapy in a more systematic way. The obtention of national data may favor the creation of assistance and public policies, considering that this radiotoxicity constitutes a limiting factor in treatment continuation, possibly interfering with disease prognosis. Also, interrupting patient treatment due to radiotoxicity leads to postponing the start of radiotherapy for other patients, leading to a negative economic impact for the service.

This study's limitations include the fact that only one nurse performed skin assessment, even though the scale is well-defined concerning the objective criteria related to the signs. However, since the same person assessed the skin of all participants, the results were not biased by differences between evaluators.

The sample sizes of each group are not large, which could be considered a limitation. However, since this is an estimation study, sample size is reflected in the confidence interval size of each estimate. For a higher precision (i.e., smaller confidence intervals), bigger samples would be necessary, which could be calculated departing from this study. Despite this limitation, the results can be generalized to cancer patient populations in Brazil with the same inclusion and exclusion criteria, similar socioeconomic characteristics, and receiving radiation in circumstances which are like those of patients in this sample.

\section{CONCLUSION}

In this study, the incidence of radiodermatitis was $100 \%$ among patients whose region of head and neck was irradiated, $98 \%$ among those whose breast region was irradiated, and $48 \%$ among those whose pelvis (cervix, endometrium, and prostate) was irradiated.

The need for identifying the incidence of this radiotoxicity nationwide is emphasized, since it is necessary to create and standardize protocols and recommendations for proper management of radiodermatitis, specially concerning its prevention.

\section{RESUMO}

Objetivo: Estimar a incidência e a distribuição de graduação de radiodermatite em pacientes com câncer submetidos à radioterapia nas regiões de cabeça e pescoço, mama e pelve. Método: Estudo prospectivo, longitudinal, quantitativo, realizado durante o período de 15 de março de 2016 a 4 de maio de 2017 com pacientes observados ao longo de cinco semanas de tratamento. O desfecho primário foi proporção de radiodermatite grau 1 ou superior em cada semana. Graduação de radiodermatite e tempo médio para a primeira ocorrência em cada paciente foram desfechos secundários. Resultados: Participaram 112 pacientes. A incidência de radiodermatite foi de $100 \%$ entre os que irradiaram a região de cabeça e pescoço, seguida por $98 \%$ em mama e $48 \%$ na pelve. A graduação de radiodermatite variou de acordo com o local da irradiação, com piores graduações na região de cabeça e pescoço, seguida por mama. Nos três grupos, o tempo médio para a primeira ocorrência de radiodermatite foi de aproximadamente 11 dias. Conclusão: A incidência de radiodermatite foi alta nos grupos estudados, o que reitera a necessidade de se fazer a mesma avaliação em âmbito nacional. Essa avaliação incentivaria 
a criação e a uniformização de protocolos e recomendações para o manejo adequado da radiodermatite, principalmente no que concerne à sua prevenção.

\section{DESCRITORES}

Radiodermatite; Neoplasias de Cabeça e Pescoço; Neoplasias da Mama; Neoplasias Pélvicas; Enfermagem Oncológica.

\section{RESUMEN}

Objetivo: Estimar la incidencia y la distribución del grado de radiodermatitis en pacientes con cáncer sometidos a radioterapia en las regiones de la cabeza y el cuello, la mama y la pelvis. Método: Estudio prospectivo, longitudinal y cuantitativo realizado entre el 15 de marzo de 2016 y el 4 de mayo de 2017 con pacientes observados durante cinco semanas de tratamiento. El resultado primario fue la proporción de radiodermatitis grado 1 o superior cada semana. El grado de radiodermatitis y el tiempo medio de la primera aparición en cada paciente fueron resultados secundarios. Resultados: Participaron 112 pacientes. La incidencia de radiodermatitis fue del 100\% entre los que se irradiaron en la región de la cabeza y el cuello, seguida del $98 \%$ en la mama y el $48 \%$ en la pelvis. El grado de radiodermatitis variaba según el sitio de irradiación, con peores grados en la región de la cabeza y el cuello, seguida de la mama. En los tres grupos, el tiempo medio para la primera aparición de radiodermatitis fue de aproximadamente 11 días. Conclusión: La incidencia de la radiodermatitis fue elevada en los grupos estudiados, lo que reitera la necesidad de hacer la misma evaluación en todo el país. Esta evaluación fomentaría la creación y la uniformización de los protocolos y recomendaciones para el manejo adecuado de la radiodermatitis, especialmente en lo que respecta a su prevención.

\section{DESCRIPTORES}

Radiodermatitis; Neoplasias de Cabeza y Cuello; Neoplasias de la Mama; Neoplasias Pélvicas; Enfermería Oncológica.

\section{REFERENCES}

1. Seité S, Bensadoun RJ, Mazer JM. Prevention and treatment of acute and chronic radiodermatitis. Breast Cancer (Dove Med Press). 2017;9:551-7. doi: http://dx.doi.org/10.2147/BCTT.S149752

2. Robijns J, Laubach HJ. Acute and chronic radiodermatitis: clinical signs, pathophysiology, risk factors and management options. J Egyptian Women's Dermatol Soc. 2018;15(1):2-9. doi: http://dx.doi.org/10.1097/01.EWX.0000529960.52517.4C

3. Partl R, Jonko B, Schnidar S, Schollhammer M, Bauer M, Singh S, et al. 128 SHADES OF RED: objective remote assessment of radiation dermatitis by augmented digital skin imaging. Stud Health Technol Inform. 2017;236:363-74.

4. Hegeus F, Mathew LM, Schwartz A. Radiation dermatitis: an overview. Int J Dermatol. 2016;56(9):909-14. doi: http://dx.doi.org/10.1111/ ijd. 13371

5. Bostock S, Bryan J. Radiotherapy-induced skin reactions: assessment and management. Br J Nurs. 2016;25(4):S18, S20-4. doi:https://doi. org/10.12968/bjon.2016.25.4.S18

6. Kole AJ, Kole L, Moran MS. Acute radiation dermatitis in breast cancer patients: challenges and solutions. Breast Cancer (Dove Med Press). 2017;5(9):313-23. doi: http://dx.doi.org/10.2147/BCTT.S109763.

7. Schmeell LC, Koch D, Stumpf S, Leitzen C, Simon C, Schüller H, et al. Prophylactically applied Hydrofilm polyurethane film dressings reduce radiation dermatitis in adjuvant radiation therapy of breast cancer patients. Acta Oncol. 2018;57(7):908-15. doi: http://dx.doi.or g/10.1080/0284186X.2018.1441542

8. Robijns J, Censabella S, Claes S, Pannekoeke L, Buss L, Colson D, et al. Prevention of acute radiodermatitis by photobiomodulation: a randomized, placebo-controlled trial in breast cancer patients (TRANSDERMIS Trial). Lasers Surg Med. 2018;50(7):763-71. doi: http:// doi.org/10.1002/lsm.22804

9. Ding J, Gou Y, Li Q, Chen J, Hu P, Liu Q, et al. The incidence of postoperative radiotherapy-induced acute dermatitis in breast cancer and its influencing factors for Chinese women. Onco Targets Ther. 2018;11:1665-70. doi: http://dx.doi.org/10.2147/OTT.S156066

10. Yee C, Wang K, Asthana R, Drost L, Lam H, Lee J, et al. Radiation-induced skin toxicity in breast cancer patients: a systematic review of randomized trials. Clin Breast Cancer. 2018;18(5):e825-40. doi: https://doi.org/10.1016/j.clbc.2018.06.015

11. Sekiguchi K, Akahane K, Ogita M, Haga C, Ito R, Arai S, et al. Efficacy of heparinoid moisturizer as a prophylactic agent for radiation dermatitis following radiotherapy after breast-conserving surgery: a randomized controlled trial. Jpn J Clin Oncol. 2018;48(5):450-7. doi: http://dx.doi.org/10.1093/jjco/hyy045

12. Singh M, Alavi A, Wong R, Akita S. Radiodermatitis : a review of our current understanding. Am J Clin Dermatol. 2016;17(3):277-92. doi: http://dx.doi.org/10.1007/s40257-016-0186-4.

13. Reis PED, Ferreira EB, Bontempo PMS. Radiodermatites: prevenção e tratamento. In: Diretrizes Oncológicas [Internet]. Brasília; 2018 [citado 2019 out. 21]. Disponível em: https://diretrizesoncologicas.com.br/wp-content/uploads/2018/10/Diretrizes-oncol\%C3\%B3gicas-2_Parte41.pdf

14. Ryan JL. Ionizing radiation: the good, the bad, and the ugly. J Invest Dermatol. 2012;132(3):985-93. doi: http://dx.doi.org/10.1038/ jid.2011.411

15. Hafner MF, Fetzner L, Hassel JC, Debus J, Potthoff K. Prophylaxis of acute radiation dermatitis with an innovative FDA-approved two-step skin care system in a patient with head and neck cancer undergoing a platin-based radiochemotherapy : a case report and review of the literature. Dermatology. 2013;227(2):171-4. doi: http://dx.doi.org/10.1159/000353974

16. Lacovelli NA, Galaverni M, Cavallo A, Facchinetti N, Lotti C, Falai C, et al. Prevention and treatment of radiation-induced acute dermatitis in head and neck cancer patients: a systematic review. Future Oncol. 2017;14(3):291-305. doi: http://dx.doi.org/10.2217/fon-2017-0359

17. Trueman E, Taylor L. Using a soft-silicone dressing to treat moist desquamation. Br J Nurs. 2014;23(10):S32, S34-7. doi: http://dx.doi. org/10.12968/bjon.2014.23.Sup10.S32

18. Alexopoulou E, Katsila T, Tolia M, Tsoukalas N, Leontsinidis M, Kyrgias G, et al. An exploratory study of radiation dermatitis in breast cancer patients. Anticancer Res. 2018;38(3):1615-22. doi: http://dx.doi.org/10.21873/anticanres.12392

19. Beamer LC, Grant M. Longitudinal trends in skin-related and global quality of life among women with breast radiodermatitis: a pilot study. Eur J Oncol Nurs. 2018;33:22-7. doi: http://dx.doi.org/10.1016/j.ejon.2018.01.008 
20. Caetano RDS, Volpato LER, Castro PHDS, Borba AM, Aranha AMF, Kuga MC, et al. Smoking influences the occurrence of radiodermatitis in head and neck-irradiated patients. World J Dentistry. 2017;8(1):55-8. doi: https://doi.org/10.5005/jp-journals-10015-1411

21. Liang X, Bradley JÁ, Zheng D, Rutenberg M, Yeung D, Mendenhall N, et al. Prognostic factors of radiation dermatitis following passivescattering proton therapy for breast cancer. Rad Oncol. 2018;13:72. doi: http://dx.doi.org/10.1186/s13014-018-1004-3

22. Morgan, K. Radiotherapy-induced skin reactions: prevention and cure. Br J Nurs. 2014; 23(16):S24, S26-32. doi: http://dx.doi.org/10.12968/ bjon.2014.23.Sup16.S24

23. Cruz FOAM, Faria ET, Reis PED. Validação de manual educativo para pacientes com câncer de mama submetidas à radioterapia. Rev Latino Am Enfermagem. 2020;28:e3384. doi: https://doi.org/10.1590/1518-8345.3197.3384

24. Cruz FOAM, Ferreira EB, Vasques CI, Mata LRF, Reis PED. Validação de manual educativo para pacientes com câncer de cabeça e pescoço submetidos à radioterapia. Rev Latino Am Enfermagem. 2016;24:2706-12. doi: https://doi.org/10.1590/1518-8345.0949.2706

25. Lucas AS, Lacouture M, Thompson J, Schneider SM. Radiation Dermatitis: a prevention protocol for patients with breast cancer. Clin J Oncol Nurs. 2018;22(4):429-37. doi: http://dx.doi.org/ 10.1188/18.CJON.429-437

Financial support

Conselho Nacional de Desenvolvimento Científico e Tecnológico (CNPq). Edital Universal, Process n. 432802/2016-9. 